\title{
Effects of release size on survival and growth of Japanese flounder Paralichthys olivaceus in coastal waters off Iwate Prefecture, northeastern Japan
}

\author{
Yoh Yamashita ${ }^{1}$, Sachio Nagahora ${ }^{2}$, Hideaki Yamada ${ }^{1}$, Daiji Kitagawa ${ }^{1}$ \\ ${ }^{1}$ Tohoku National Fisheries Research Institute, Shinhama, Shiogama, Miyagi 985, Japan \\ ${ }^{2}$ Iwate Prefectural Nanbu Sea-farming Center, Matsuzaki, Ofunato, Iwate 022, Japan
}

\begin{abstract}
A total of 35900 in 1990 and 73400 in 1991 otolith-marked, hatchery-raised Japanese flounder Paralichthys olivaceus fry ranging from 4 to $15 \mathrm{~cm}$ total length (TL) were released into shallow water at depths of 4 to $8 \mathrm{~m}$ at Ohno Bay, northeastern Japan. The otoliths of the fish were marked 1 to $3 \mathrm{~d}$ prior to release with an alizarin complexone fluorescent marker The size at release of flounder recaptured by a beam trawl, set net and commercial catch was estimated using the fluorescent mark diameter to TL relationship, and survival and growth rates were examined. As time progressed after release, back-calculated release size distributions gradually shifted to larger values. The flounder fry $>9 \mathrm{~cm}$ at release were successful in recruiting to commercial fisheries. The major cause of mortality was thought to be predation by large flounder and greenling Hexagrammos otakii which were abundant in the flounder nursery ground. Growth rate of released flounder was high in the warm and low in the cold season. Individual growth rates were estimated by otolith mark diameter and TL at catch. The relationship of release size and growth rate analyzed in the flounder recaptured 11 mo after release indicated that survival of released flounder is strongly associated with size itself and growth rate in the field.
\end{abstract}

KEY WORDS: Flounder - Survival - Growth - Mark and recapture

\section{INTRODUCTION}

The Japanese flounder Paralichthys olivaceus is one of the most important commercial fishes in Japan, where it is distributed in all coastal waters except around the Okinawan Islands. Eggs are spawned offshore in 30 to $100 \mathrm{~m}$ depth and the larvae of 1.2 to $1.6 \mathrm{~cm}$ total length (TL) settle in sandy areas shallower than $10 \mathrm{~m}$ during spring and summer (Imabayashi 1980a, b, Minami 1982, Tanaka et al. 1989). Young fish 10 to $15 \mathrm{~cm}$ TL leave the nursery ground and migrate to deeper waters from autumn to early winter of the first year (Imabayashi 1980b, Y. Yamashita, S. Nagahora, K. Igarashi \& K. Sato unpubl.).

Stocking of this species has been carried out extensively in Japan since 1980 under the sea-farming project of the Japanese Fishery Agency. A total of about 14 million hatchery-raised fry ranging from 3 to $12 \mathrm{~cm}$ TL were released in 1990.

In order to determine the most appropriate fish size for stocking, mark-and-recapture studies have been conducted with Japanese flounder (Nihira et al. 1988, 1992) and red sea bream Pagrus major, another stocked coastal species (Tsukamoto et al. 1989). However, restricted data on the relationship of survival rate to size at release were collected due to limitations of the tagging procedure, overlap in size groups and difficulty in assessing the degree of tag loss.

We marked the otoliths of juvenile flounder fry a few days before release and conducted releaserecapture experiments in the field. The release size of recaptured fish was estimated by the mark diameter to total length relationship. Using this method, we studied the survival and growth rate from release to 
market size in relation to size at release with better accuracy than the conventional studies mentioned above and we discuss the causes of mortality in the field.

Although stocking of flounder is a commercial venture, the situation represents a unique and valuable opportunity to conduct scientific experiments using large-scale mark and release, and recapture by commercial fisheries.

\section{MATERIALS AND METHODS}

Marking of otoliths. Japanese flounder fry for experimental release were raised at the Iwate Prefectural Nanbu Sea-farming Center in 1990 and 1991. In order to prepare a wide range of sizes for release, parental stock were induced to spawn at various times from late April to late May. Juveniles were immersed for $24 \mathrm{~h}$ in an $80 \mathrm{ppm}$ solution of alizarin complexone (ALC, Dojindo) 1 to $3 \mathrm{~d}$ before release. We have confirmed that the ALC mark on the otolith remains for at least 2.5 yr after marking (Yamashita unpubl.). Survival rate of flounder fry during marking ranged from 90.3 to $97.5 \%$ in 1990 and from 97.4 to $98.7 \%$ in 1991 . There was no size-specific mortality and lowering the density (fish weight to water volume) and careful aeration improved survival rate. It has been reported that massmarking procedures of otoliths had no effect on fish growth and mortality for ayu Plecoglossus altivelis (Tsukamoto 1985) and red sea bream (Kuwada \& Tsukamoto 1987). The relationship between sagittal otolith longest diameter (OD) and TL at release was linear as follows:

Released in $1990,5.2$ to $14.8 \mathrm{~cm}$ TL range:

Left side

$$
\mathrm{TL}=5.320 \mathrm{OD}-3.962, \quad \mathrm{R}=0.963, \quad \mathrm{~N}=60
$$

Right side

$$
\mathrm{TL}=5.272 \mathrm{OD}-3.668, \quad \mathrm{R}=0.955, \quad \mathrm{~N}=60
$$

Released in $1991,4.4$ to $14.7 \mathrm{~cm}$ TL range:

Left side

$$
\mathrm{TL}=5.014 \mathrm{OD}-2.528, \quad \mathrm{R}=0.973, \quad \mathrm{~N}=55
$$

Right side

$$
\mathrm{TL}=5.118 \mathrm{OD}-2.771, \quad \mathrm{R}=0.977, \quad \mathrm{~N}=55
$$

There was no significant difference among the 4 regressions (ANCOVA, $\mathrm{p}>0.05$ ).

Study area, release and sampling of fish. We transported by boat 35900 fish ranging from 5 to $15 \mathrm{~cm} \mathrm{TL}$ in two 1000 l containers from the Nanbu Center to Ohno Bay (Fig. 1) and released them in an area of 4 to $8 \mathrm{~m}$ depth on 6 September 1990. In 1991, we released 73400 fish of 4 to $15 \mathrm{~cm} \mathrm{TL}$ at the same site on 30 August. Monthly average surface water temperature,

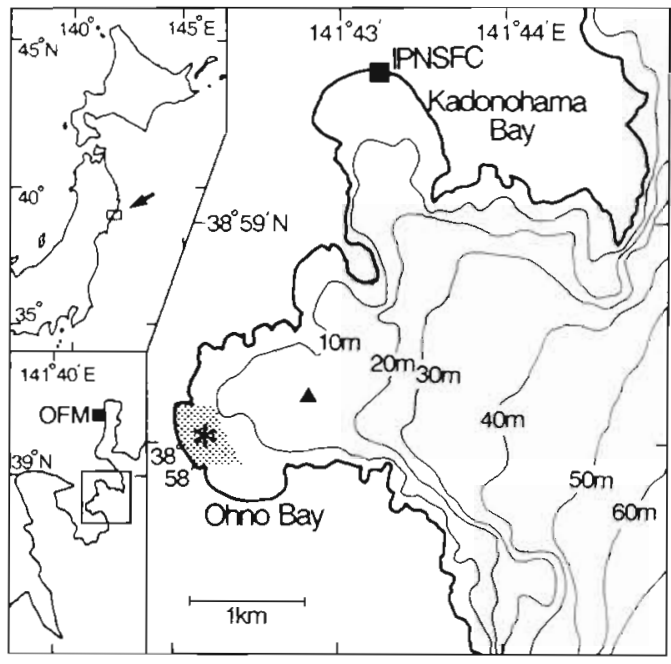

Fig. 1. Release and sampling sites, Ohno Bay, Japan. (*) Release point; dotted area: sampling area via beam trawl; ( $\mathbf{\Lambda}$ ) location of set net; OFM: Ofunato Fish Market; IPNSFC: Iwate Prefectural Nanbu Sea-farming Center

which was calculated from daily measurements at the head of Kadonohama Bay next to Ohno Bay at 9:00 h, was lowest (ca $8^{\circ} \mathrm{C}$ ) in February and March and highest (ca $22^{\circ} \mathrm{C}$ ) in August and September (Fig. 2). Sampling of released fish was carried out by a beam trawl of $2 \mathrm{~m}$ width, $0.3 \mathrm{~m}$ height and $3 \mathrm{~mm}$ mesh aperture designed after Kuipers (1975). This gear has a $26.7 \%$ fishing efficiency for juvenile flounders (Fujii et al. 1989). The beam trawl was towed at a speed of 0.5 to $1.0 \mathrm{~m} \mathrm{~s}^{-1}$. Age $1+$ and $2+$ flounder were caught by a set net in Ohno Bay from 21 July to 10 August 1992. In addition, we collected the heads of commercial-size

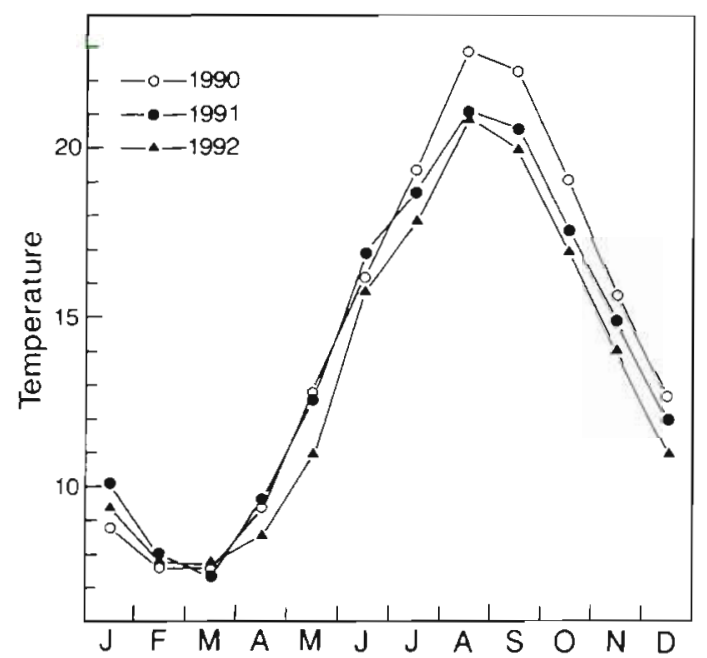

Fig. 2. Seasonal changes in surface seawater temperature at the head of Kadonohama Bay. Monthly averages, measured daily at $9: 00 \mathrm{~h}$ 
flounder landed at the Ofunato Fish Market and data on individual fish, i.e. TL, catch date and catch site. Because the price of flounder is very high (approximately US $\$ 30 \mathrm{~kg}^{-1}$ ) it was difficult to buy many market-sized fish. All specimens collected were preserved in $85 \%$ ethyl alcohol.

Otolith processing. Sagittae of both sides were dissected out and the diameter of pink colored ring (Fig. 3) measured under a dissecting microscope. Sagittae of older fish and those with marks not readily detectable were ground to facilitate reading and the presence of fluorescent mark checked under a UV light microscope. The age of fish was determined by reading semi-annual rings on the sagittae using the method of Kitagawa et al. (1994). Size at release was calculated from the estimate of year of release (age) and from the ALC mark diameter using the otolith diameter to TL relationship given above. A mean value of right and left sagitta was used to estimate size at release. In almost all cases the difference between right and left sagitta of estimated TL values was less than $7 \%$. Also the daily growth rate in the field after release $(G)$ was calculated by:

$$
G=\left(\mathrm{TL}_{\mathrm{rec}}-\mathrm{TL}_{\mathrm{rel}}\right) / D
$$

where $\mathrm{TL}_{\text {rec }}$ is TL at recapture; $T L_{\text {rel }}$ is back-calculated TL at release; and $D$ is days after release.

Release size index. In order to determine the appropriate release size, we adopted a release size index (RSI) defined below.

We considered 10 total length classes at release, each with a $1 \mathrm{~cm}$ range, from 5.0 to $15.0 \mathrm{~cm}$ for 1990 fry and 11 size classes from 4.0 to $15.0 \mathrm{~cm}$ fry for 1991 .

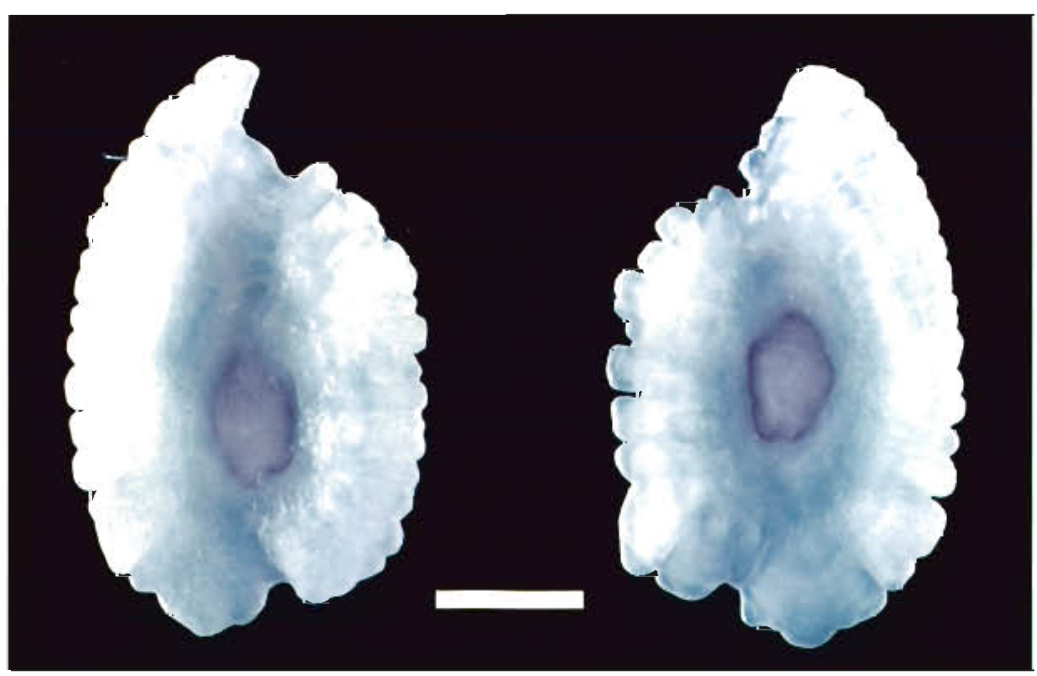

Fig. 3. Paralichthys olivaceus. Sagittae of Japanese flounder, total length (TL) $37.9 \mathrm{~cm}$. Back-calculated release size was $6.1 \mathrm{~cm} \mathrm{TL}$. Left: left sagitta; right: right sagitta; scale bar $=2 \mathrm{~mm}$
For example, the TL $5 \mathrm{~cm}$ group includes sizes from 5.0 to $5.9 \mathrm{~cm}$. The RSI of this group $\left(\mathrm{RSI}_{5}\right)$ is:

$$
\mathrm{RSI}_{5}=P_{5 \text { rec }} / P_{5 \text { rel }}
$$

where $P_{5 \text { rel }}$ is the ratio of the total number of the $5 \mathrm{~cm}$ TL class to the total number of fry released; and $P_{5 \text { rec }}$ is the ratio of back-calculated $5 \mathrm{~cm}$ TL class at release to the total number of recaptured fish.

Values larger than 1 and smaller than 1 indicate better and worse than average survival respectively.

\section{RESULTS}

\section{Survival in relation to release size}

Of the 1990 release group, we collected 217 tagged flounder by beam trawl between 7 September 1990 and 4 July 1991 and 77 fish from the market and set net from 26 September 1991 to 22 December 1992. For the 1991 release group we also collected 78 tagged fish within 3 mo after release, mainly by the beam trawl, and sampled 134 fish from the set net and the market between 18 July 1992 and 18 December 1992 .

For the fish released in 1990, back-calculated average size at release for 1 mo after release $(9.30 \pm$ $1.49 \mathrm{~cm}, \mathrm{~N}=191$ ) was significantly smaller than actual release size ( $t$-test, $p<0.01$; Table 1 ). Besides, the average size at catch was smaller than actual release size in 3 samples carried out within $1 \mathrm{wk}$ after release, but the difference was not significant ( $t$-test, $\mathrm{p}>0.1$ ). Back-calculated release size increased after 1 mo of release and was $>10 \mathrm{~cm}$ for market and set net samples. Average back-calculated release size for all market and set net sample $(10.33 \pm 1.32 \mathrm{~cm}, \mathrm{~N}=77)$ was significantly larger than the actual release size ( $t$-test, $\mathrm{p}<0.05$ ). The results of the study on fish released in 1991 showed the same tendency as those in 1990 (Table 2). Both back-calculated release size and catch size collected on 5 September, 6 d after release, were smaller than the actual release size. The difference was significant for the back-calculated release size (t-test, $p<0.01)$ and not significant for catch size ( $t$-test, $p>0.4)$. Back-calculated release size increased as time progressed and the average size of the set net and market sample (10.89 \pm $1.25 \mathrm{~cm}, \mathrm{~N}=134$ ) was significantly larger than the actual release size ( $t$-test, $\mathrm{p}<0.01$ ). 
Table 1. Paralichthys olivaceus. Sampling date, total length at catch, back-calculated total length at release and growth rate of flounder released on 6 September 1990. Means \pm SD

\begin{tabular}{|c|c|c|c|c|c|c|c|}
\hline \multirow{2}{*}{ Date } & \multirow{2}{*}{ Age } & \multirow{2}{*}{$N$} & \multicolumn{2}{|c|}{ Total length $(\mathrm{cm})$} & \multirow{2}{*}{$\begin{array}{l}\text { Days after } \\
\text { release }\end{array}$} & \multirow{2}{*}{$\begin{array}{c}\text { Daily growth } \\
\text { rate }(\mathrm{mm})\end{array}$} & \multirow{2}{*}{$\begin{array}{l}\text { Sample } \\
\text { source }\end{array}$} \\
\hline & & & At release & At catch & & & \\
\hline 6 Sep 90 & $0+$ & 200 & $9.87 \pm 1.64$ & - & 0 & - & Release \\
\hline 7 Sep 90 & $0+$ & 64 & $9.54 \pm 1.43$ & $9.49 \pm 1.37$ & 1 & $-0.53 \pm 3.22$ & Trawl \\
\hline 11 Sep 90 & $0+$ & 44 & $9.24 \pm 1.71$ & $9.37 \pm 1.68$ & 5 & $0.25 \pm 0.63$ & Trawl \\
\hline 13 Sep 90 & $0+$ & 43 & $9.17 \pm 1.34$ & $9.78 \pm 1.54$ & 7 & $0.88 \pm 1.11$ & Trawl \\
\hline 25 Sep 90 & $0+$ & 26 & $9.31 \pm 1.46$ & $10.45 \pm 1.66$ & 19 & $0.60 \pm 0.47$ & Trawl \\
\hline 4 Oct 90 & $0+$ & 14 & $8.79 \pm 1.37$ & $9.82 \pm 1.36$ & 28 & $0.37 \pm 0.19$ & Trawl \\
\hline 13 Nov 90 & $0+$ & 9 & $10.01 \pm 1.65$ & $13.77 \pm 2.98$ & 68 & $0.55 \pm 0.29$ & Trawl \\
\hline 6 Dec 90 & $0+$ & 1 & 10.6 & 14.8 & 91 & 0.46 & Trawl \\
\hline 30 May 91 & $1+$ & 11 & $9.87 \pm 1.01$ & $15.78 \pm 2.27$ & 266 & $0.22 \pm 0.09$ & Trawl \\
\hline 4. Jul 91 & $1+$ & 5 & $10.00 \pm 1.12$ & $17.88 \pm 2.56$ & 301 & $0.26 \pm 0.10$ & Trawl \\
\hline 26 Sep $91-21$ Dec 91 & $1+$ & 31 & $10.55 \pm 1.14$ & $29.84 \pm 1.89$ & $385-471$ & $0.45 \pm 0.05$ & Market \\
\hline 16 Jan $92-18$ Jul 92 & $1+, 2+$ & 8 & $10.23 \pm 1.92$ & $31.35 \pm 1.41$ & $497-681$ & $0.36 \pm 0.06$ & Market \\
\hline $20 \mathrm{Jul} 92-10$ Aug 92 & $2+$ & 24 & $10.03 \pm 1.02$ & $29.81 \pm 2.51$ & $683-704$ & $0.28 \pm 0.04$ & Set net \\
\hline 14 Sep $92-22$ Dec 92 & $2+$ & 14 & $10.40 \pm 1.52$ & $36.61 \pm 3.29$ & $739-838$ & $0.33 \pm 0.04$ & Market \\
\hline
\end{tabular}

The back-calculated release size distribution (Fig. 4) and RSI (Fig. 5) showed a higher mortality rate for the smaller-released fish. The highest frequency of the back-calculated release size was for the TL groups 8 to $10 \mathrm{~cm}$; fry $>11 \mathrm{~cm}$ at release were less frequently recaptured in the first month after release in 1990 (Fig. 4). The percentage of small fish at release decreased as time progressed and the number of recaptured fish $<8 \mathrm{~cm}$ at release became negligible after the first winter. More than $95 \%$ of the $1+$ and $2+$ flounder were from the 8 to $13 \mathrm{~cm}$ TL of the back-calculated release sizes.

In 1991, we prepared flounder fry for release with a broader and a more evenly spread distribution over the size range in order to study the effect of release size on survival in the field more clearly (Fig. 4). Similar to the result of 1990 study, the percentage of large fry recaptured $6 \mathrm{~d}$ after release was smaller compared to that at release. However, from 1 mo after release the percentage of small-released fish decreased more rapidly and evidently than in 1990 . Flounder $<7 \mathrm{~cm}$ at release were not recaptured during sampling in 1992.
RSI of flounder fry recaptured in September 1990 declined with release size (Fig. 5). Though RSI of the 5 and $6 \mathrm{~cm}$ groups collected in October-December 1990 decreased compared with those of September, the declining tendency with size was the same as in September. RSI of $1+$ and $2+$ flounder was $>1$ for the release sizes from 9 to $13 \mathrm{~cm}$ TL. From September to October/November for 1991-released flounder, the decrease of RSI for small fish, 5 to $8 \mathrm{~cm}$ TL at release, was strongly evident. The positive RSI of $1+$ flounder ranged from 9 to $14 \mathrm{~cm} \mathrm{TL}$ at release.

\section{Growth in the field}

The average daily growth rate in the hatchery from hatching to release was $0.80 \mathrm{~mm}$ in 1990 and $0.85 \mathrm{~mm}$ in 1991. Average release size was $9.87 \mathrm{~cm}$ in 1990 and $9.59 \mathrm{~cm}$ in 1991. Back-calculated daily growth rates of the fry caught within $1 \mathrm{wk}$ after release $(7,11,13$ September in 1990 and 5 September in 1991) seem to

Table 2. Paralichthys olivaceus. Sampling date, total length at catch, back-caiculated total length at release and growth rate

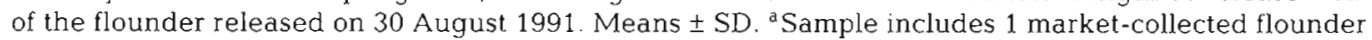

\begin{tabular}{|c|c|c|c|c|c|c|c|}
\hline \multirow[t]{2}{*}{ Date } & \multirow[t]{2}{*}{ Age } & \multirow[t]{2}{*}{$N$} & \multicolumn{2}{|c|}{ Total length $(\mathrm{cm})$} & \multirow{2}{*}{$\begin{array}{c}\text { Days after } \\
\text { release }\end{array}$} & \multirow{2}{*}{$\begin{array}{l}\text { Daily growth } \\
\text { rate (mm) }\end{array}$} & \multirow{2}{*}{$\begin{array}{l}\text { Sample } \\
\text { source }\end{array}$} \\
\hline & & & At release & At catch & & & \\
\hline 30 Aug 91 & $0+$ & 200 & $9.59 \pm 2.68$ & - & 0 & - & Release \\
\hline 5 Sep 91 & $0+$ & 55 & $8.39 \pm 1.78$ & $9.30 \pm 2.23$ & 6 & $1.52 \pm 1.33$ & Trawl \\
\hline 15 Oct 91 & $0+$ & 7 & $8.61 \pm 1.96$ & $11.26 \pm 2.42$ & 46 & $0.57 \pm 0.25$ & Trawl \\
\hline 25 Oct 91 & $0+$ & 10 & $10.71 \pm 0.87$ & $18.09 \pm 0.94$ & 56 & $1.32 \pm 0.19$ & Bait fishing \\
\hline 6 Nov 91 & $0+$ & 6 & $9.62 \pm 1.95$ & $15.23 \pm 2.34$ & 68 & $0.83 \pm 0.23$ & Trawl \\
\hline 20 Jul 92-10 Aug 92 & $1+$ & 122 & $10.93 \pm 1.27$ & $21.82 \pm 2.00$ & $325-346$ & $0.33 \pm 0.06$ & Set net ${ }^{a}$ \\
\hline 14 Sep $92-18$ Dec 92 & $1+$ & 12 & $10.56 \pm 0.93$ & $30.60 \pm 2.69$ & $381-476$ & $0.49 \pm 0.06$ & Market \\
\hline
\end{tabular}




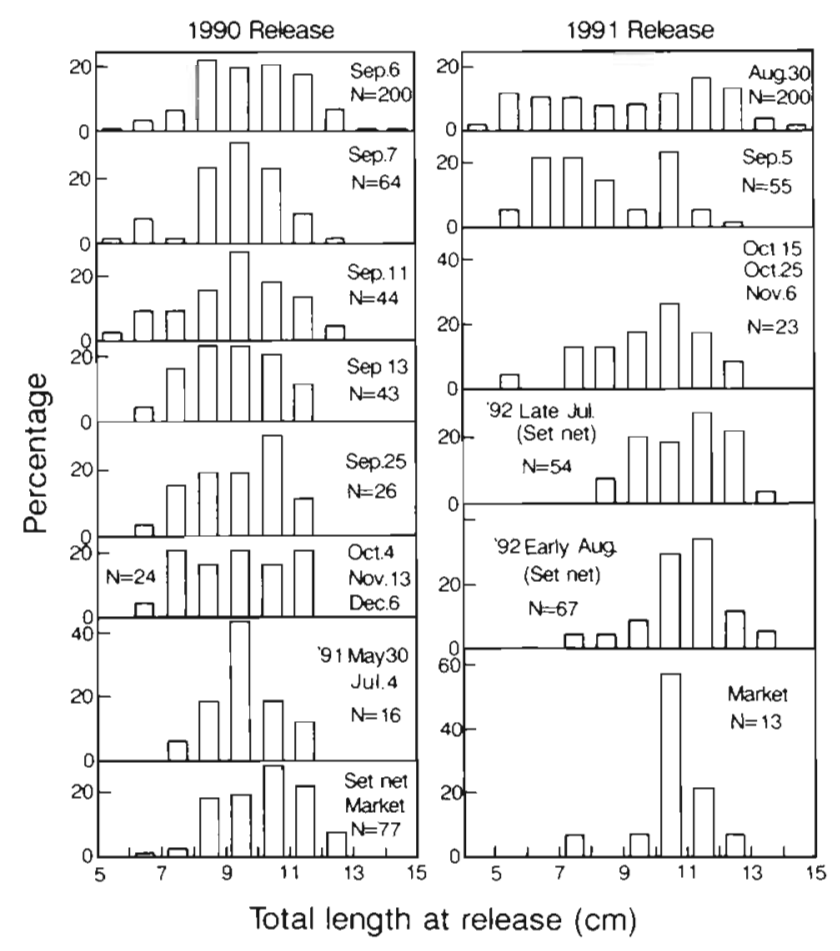

Fig. 4. Paralichthys olivaceus. Distribution of back-calculated total length at release. Data of 6 Sep 1990 and 30 Aug 1991 are the actual size-frequency distributions at release

be strongly affected by both transient stunting and deviations from the otolith diameter to TL regression formula (Tables $1 \& 2$ ).

Average back-calculated daily growth rates of the flounder released in 1990 and caught on 25 September,

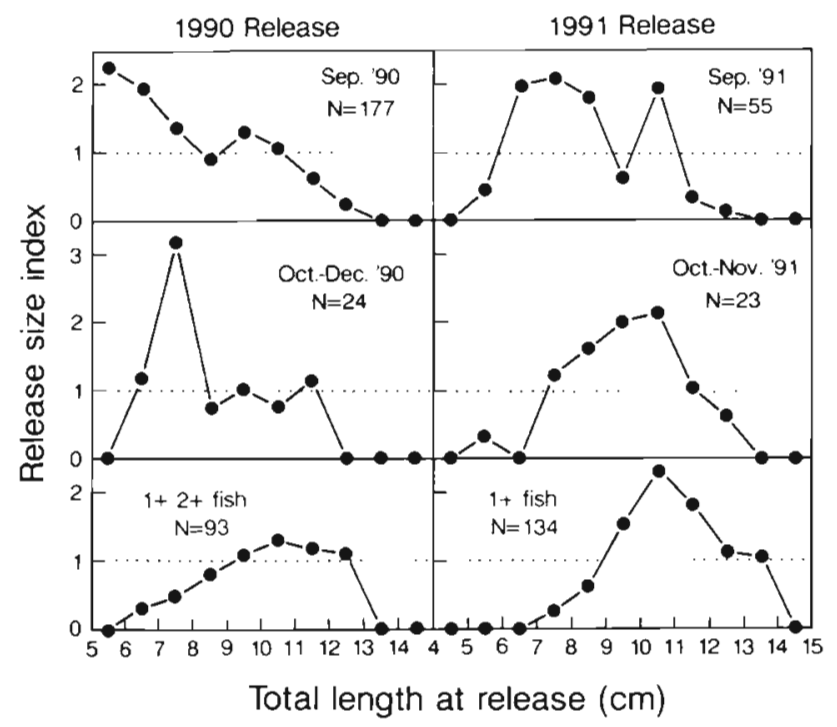

Fig. 5. Paralichthys olivaceus. Release size index (see text) distribution for 1990- and 1991-released flounder
4 October, 13 November and 6 December were 0.60 , $0.37,0.55,0.46 \mathrm{~mm}$ respectively (Table 1 ). The average growth rate during this period, the first autumn for the fish, was $0.52 \mathrm{~mm} \mathrm{~d}^{-1}$. Daily growth rates of flounder from the 30 May and 4 July samplings were low, 0.22 and $0.26 \mathrm{~mm}$. That of $2 \mathrm{yr}$ old fish collected by the set net in late July to early August was also low $(0.28 \mathrm{~mm})$. Daily growth rates of flounder sampled from the market from September to December were $0.45 \mathrm{~mm}$ for 1 yr old fish and $0.33 \mathrm{~mm}$ for 2 yr old fish. As with the flounder released in 1990, growth rate of flounder released in 1991 (Table 2) was high in the first autumn $\left(0.96 \mathrm{~mm} \mathrm{~d}^{-1}\right)$, low for the fish collected early next summer $\left(0.33 \mathrm{~mm} \mathrm{~d}^{-1}\right)$, and for $1 \mathrm{yr}$ old fish collected from the market during second September to December a value was $0.49 \mathrm{~mm} \mathrm{~d}^{-1}$.

Seasonal change of TL (Fig. 6) showed that growth rate was high during the warm season $\left(>15^{\circ} \mathrm{C}\right)$ from early summer to late autumn and low over the cold period in the field. Values of daily growth rate estimated from the slopes of TL at recapture (Fig. 6) were $0.60 \mathrm{~mm}$ in the first warm season (release to early December 1990 ) $0.13 \mathrm{~mm}$ in the first cold season (November 1990 to early July 1991), $0.77 \mathrm{~mm}$ in the second warm season (30 May to November 1991), $0.08 \mathrm{~mm}$ in the second cold season (December 1991 to early August 1992), and $0.67 \mathrm{~mm}$ in the third warm season (July to December 1992). Also the growth rate of fish released in 1991 was $1.00 \mathrm{~mm} \mathrm{~d}^{-1}$ in the first warm season (release to early November), $0.24 \mathrm{~mm} \mathrm{~d}^{-1}$ in the first cold season (late October 1991 to early August 1992), and $0.71 \mathrm{~mm} \mathrm{~d}^{-1}$ in

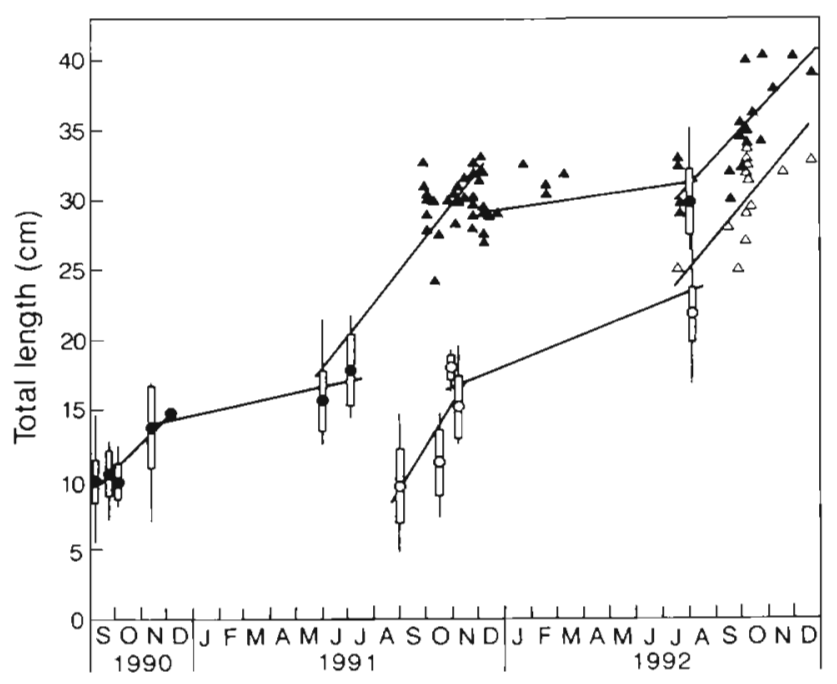

Fig. 6. Paralichthys olivaceus. Observed total length (TL) at each sampling date. (O) Mean TL of beam trawl, fishing, and set net sampling; (|) range; (0) $\pm \mathrm{SD}_{i}(\Delta, \Delta)$ flounder collected from Ofunato Fish Market. Closed and open symbols indicate flounder released in 1990 and 1991 respectively. Growth is expressed by linear regression lines calculated for each period 


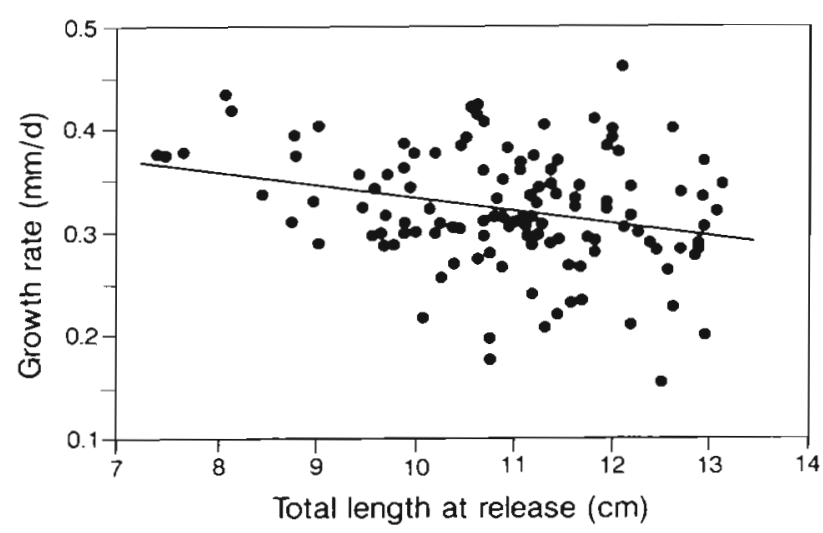

Fig. 7. Paralichthys olivaceus. Relationship between total length at release and average back-calculated daily growth rate for 1 yr old flounder collected by set net, 20 July -10

August 1992. $G=-0.0123 T L+0.4570, r=0.2730, \mathrm{~N}=121$

the second warm season (July to December 1992). Backcalculated growth rate, therefore, when an average rate of the accumulated growth in the life history after release is given, includes some periods of high growth rates during warm seasons and low growth rates during cold seasons.

There was no significant relationship between release size and growth rate during the first autumn in either 1990 or 1991 . However, we found a tendency that the smaller fish at release had a higher growth rate (Fig. 7), and the correlation coefficient was significant $(\mathrm{r}=0.2730, \mathrm{~N}=121, \mathrm{p}<0.01)$ for the 1 yr old fish collected by the set net from 20 July to 10 August 1992. It is noteworthy that flounder smaller than $9 \mathrm{~cm}$ TL at release with a growth rate less than $0.30 \mathrm{~mm} \mathrm{~d}^{-1}$ or those smaller than $10 \mathrm{~cm}$ at release with growth rate less than $0.25 \mathrm{~mm} \mathrm{~d}^{-1}$ were not recaptured in this sample.

\section{DISCUSSION}

The shift of back-calculated release size distribution and RSI distribution to larger size with time for both 1990- and 1991-released flounder (Figs. 4 \& 5) evidently demonstrates that size selective mortality of the flounder occurs between release and capture at commercial size. Possible reasons for the smaller backcalculated release size and catch size than the actual release size (Tables $1 \& 2$ ) and decline in RSI of flounder fry with release size (Fig. 5) found in the early period after release are the bias in the regression for back calculation, net avoidance and movement away from the sample area by the larger-released flounder, and transient stunting before physiological adjustment to the new environment. The back-calculated release sizes with positive RSI of 1 and 2 yr old flounder ranged from 9 to 13 or $14 \mathrm{~cm}$ TL. In addition, the $10 \mathrm{~cm}$ releasesize group gave the highest RSI in both 1990- and 1991-released fish. These results indicated that 9 to $11 \mathrm{~cm}$ TL fish are probably the most appropriate for release. But we should also consider the financial costs of raising flounder fry in order to determine the best practical release size.

This study found that larger flounder fry at release are more successful in surviving to recruitment size in the field. We think this is primarily attributable to predation levels by piscivorous fishes on the smaller flounder fry. Yamashita et al. (1993) reported that 5 predatory fishes, Japanese flounder, greenling Hexagrammos otakii, skate Raja porosa, rock fish Sebastes schlegeli, barfin flounder Verasper moseri were found to have flounder fry in their stomachs and that the former 2 species appeared to be the major predators on flounder fry. Both adult flounder older than $1 \mathrm{yr}$ and greenling were abundant around the nursery ground during the release season. The percentage of fish having flounder fry in their stomachs during the period from 0 to $37 \mathrm{~d}$ after release was $12.8 \%$ for adult flounder and $7.6 \%$ for greenling $>15 \mathrm{~cm}$ TL. Flounder fry $<9 \mathrm{~cm}$ TL are vulnerable to predation judging from predator/prey size relationship and size distribution of predatory fishes residing in the field (Yamashita et al. 1993). The critical total length at release, $9 \mathrm{~cm}$, for positive RSI agreed well with the flounder size vulnerable to predation by carnivorous fishes. Though adult flounder leave shallow water in late autumn, large adult greenling migrate from offshore into the nursery ground for spawning in November. Therefore predation pressure may be heavy until early winter when the flounder fry leave the nursery ground to deeper water (Yamashita et al. unpubl.).

Van der Veer \& Bergman (1987) reported that predation by the brown shrimp Crangon crangon caused a significant density-dependent mortality on newly settled plaice Pleuronectes platessa juveniles. Crangonid shrimp Crangon affinis are also common in the nursery grounds of the Japanese flounder. But predation by shrimp seems to be restricted to newly settled juveniles up to $3 \mathrm{~cm}$ standard length (SL) (van der Veer \& Bergman 1987, Seikai et al. 1993). There appears to be a 3-phase predation process for wild flounder, a period of predation in the pelagic stage in late spring and early summer, a period of predation by crustaceans on newly settled fish in summer and a period of predation by fish in autumn and winter as suggested for the North Sea plaice by van der Veer et al. (1990). Hence hatchery raised flounder avoid the earlier 2 predation processes.

Generally starvation is the other main cause of mortality for fish. However, it is thought that starvation is significant only for first feeding larvae and predation 
is more important as a regulator of recruitment (Hewitt et al. 1985, Houde 1987, Bailey \& Houde 1989). Comparative studies of the recruitment mechanisms of North Sea 0-group plaice by van der Veer et al. (1990) suggested that mortality due to starvation was not common. Fifty percent mortality of unfed Japanese flounder juveniles with mean $17.3 \mathrm{~mm}$ SL occurs about $14 \mathrm{~d}$ after the start of starvation (Chantanachookhin et al. 1990) and resistance to starvation increases with increasing size. In this study, mysids, which are the primary food organisms of the flounder fry (Imabayashi 1980b, Koshiishi et al. 1991, Sudo et al. 1992), were abundant in the nursery ground. In spite of high flounder density, feeding incidence (percentage having food organisms in their stomachs) of released flounder fry quickly increased and reached about $70 \%$ by 5 or $6 \mathrm{~d}$ after release in both years (Yamashita et al. unpubl.). These information and findings support the idea that mortality of released fry caused by starvation is probably insignificant.

Although the number of flounder fry released in 1991 was twice that of 1990 , growth rate of 1991 released flounder in the first autumn was greater (0.96 $\mathrm{mm} \mathrm{d}^{-1}$ ) than that of 1990-released flounder $\left(0.52 \mathrm{~mm} \mathrm{~d}^{-1}\right)$. There were no significant differences in mysid abundance and feeding rate between 1990 and 1991 and temperature in 1991 was lower than in 1990. Though we could not confirm the cause of this growth difference, it was noted that weight percentage of fish in flounder stomachs, mostly comprised of Japanese anchovy Engraulis japonicus juveniles, was higher in 1991 than in 1990 (Yamashita et al. unpubl.). Juvenile flounder change their main food from mysids to fish at a TL between 5 and $15 \mathrm{~cm}$ depending on the availability of food organisms (Imabayashi 1980b). Anchovy juveniles are larger in size and probably nutritionally richer than mysids (Thayer et al. 1973). Also, the average growth rate until the second early winter of the 1991 -released flounder $0.49 \mathrm{~mm} \mathrm{~d}^{-1}$ was still significantly larger than $0.45 \mathrm{~mm} \mathrm{~d}^{-1}$ of 1990 fish ( $t$-test, $\mathrm{p}<0.05)$.

Daily growth rate of wild flounder juveniles from 3 nursery areas in Japan was $0.5 \mathrm{~mm}$ in Shijiki Bay (western Japan, facing the East China Sea), $1.0 \mathrm{~mm}$ in Wakasa Bay (mid-Japan, facing the Japan Sea) and $1.9 \mathrm{~mm}$ in Igarashihama (mid-northern Japan, facing the Japan Sea) (Tanaka et al. 1994). It was suggested that the differences in growth rates were generated by the amount of food organisms available and the mortality by starvation seemed severe in Shijiki Bay. Therefore the release point may be a significant factor for effective stocking. The growth rates found in our study were lower than the values in Wakasa Bay and Igarashihama. For Paralichthys species, growth rate is affected by the amount of food (Tanaka et al. 1994), temperature (Seikai et al. 1986, Malloy \& Targett 1991), and size of fish (Kusakari \& Mori 1982, Kramer 1991). Compared with the results of Tanaka et al. (1994), the lower temperature and larger size of flounder in this study in addition to transient stunting seem likely to be responsible for lower growth rates of released flounder on the Iwate coast. The growth curve up to 2 yr old estimated in our study was similar to that in Sendai Bay (Sato 1975) about $100 \mathrm{~km}$ south from the present field and higher growth rates have been reported from southern Japan (Ishida et al. 1978, Nihira et al. 1988).

We did not find a significant relationship between release size and growth rate in the first autumn in either 1990 or 1991. However, there was a significant negative correlation in the sample collected in the next early summer for 1991 release fish, implying that a continuous mortality primarily due to predation operates on small flounder until the first winter. Fig. 6 indicates that survival is strongly associated with size itself and growth rate even in the juvenile and young stages as suggested by Houde (1987) for larval fishes.

Acknowledgements. We thank K. Igarashi and the staff of Iwate Prefectural Nanbu Sea-farming Center for their help in raising and releasing flounder fry. We also thank K. M. Bailey and C. P. Norman for critically reading the manuscript.

\section{LITERATURE CITED}

Bailey, K. M., Houde, E. D. (1989). Predation on eggs and larvae of marine fishes and the recruitment problem. Adv. mar. Biol. 25: 1-83

Chantanachookhin, C., Tanaka, M., Seikai, T. (1990). Morphological and histological changes of digestive organs in starved Japanese flounder larvae, Paralichthys olvaceus In: Hirano, R., Hanyu, I. (ed.) Proc. 2nd Asian Fish. Forum. Asian Fisheries Society, Manila, p. 433-436

Fujii, T., Sudo, H., Azeta, M., Tanaka, M. (1989). Settling process of larvae and juveniles of Japanese flounder in Shijiki Bay, Hirado Island. Nippon Suisan Gakk. 55: 17-23 (in Japanese, with English summary)

Hewitt, R. P., Theilacker, G. H., Lo, N. C. (1985). Causes of mortality in young jack mackerel. Mar. Ecol. Prog. Ser. 26: $1-10$

Houde, E. D. (1987). Fish early life dynamics and recruitment variability. Am. Fish. Soc. Symp. 2: 17-29

Imabayashi, H. (1980a). Settling mechanism of larvae of bastard halibut, Paralichthys olivaceus, in the nursery ground, estimated from the size distribution. Bull. Jap. Soc. scient. Fish. 46: 419-426 (in Japanese, with English summary)

Imabayashi, H. (1980b). Feeding activities of juvenile and young bastard halibut, Paralichthys olivaceus, in the biotic community. 1. Intraspecific relationships in the population. Bull. Jap. Soc. scient. Fish. 46: 427-435 (in Japanese, with English summary)

Ishida, O., Tanaka, K., Shoji, Y. (1978). Age and growth of Japanese flounder in waters of Uchibo and Sotobo areas. Bull. Chiba Pref. Fish. Exp. Stn. 38: 31-36 (in Japanese)

Kitagawa, D., Ishito, Y., Sakurai, Y., Fukunaga, T. (1994). Age, growth and maturation of the Japanese flounder, 
Paralichthys olivaceus, in the coastal waters of northern Sanriku district. Bull. Tohoku Natl. Fish. Res. Inst. 56: (in press) (in Japanese, with English summary)

Koshiishi, Y., Itano, H., Hirota, Y (1991). Artificial stock-size improvement of the flounder Paralichthys olivaceus: present status of technological achievement. NOAA Tech. Rep. NMFS 102: 33-43

Kramer, S. H. (1991). Growth, mortality, and movements of juvenile California halibut Paralichthys californicus in shallow coastal and bay habitats of San Diego County, California. Fish. Bull. U.S. 89: 195-207

Kuipers, B. (1975). On the efficiency of a two-metre beam trawl for juvenile plaice (Pleuronectes platessa). Neth. J. Sea Res. 9: 69-85

Kusakari, M., Mori, Y. (1982). Studies on rearing methods of the bastard halibut, Paralichthys olivaceus. 1. Effects of rearing water temperature on survival and growth of juvenile fish. J. Hokkaido Fish. Exp. Stn. 39: 305-319 (in Japanese)

Kuwada, H., Tsukamoto, K. (1987). Otolith-tagging of the red sea bream larvae with alizarin complexon. 1. Optimum concentration and mark retention. Saibai-gyogyo Gijutsukaihatsu Kenkyu 16: 93-104 (in Japanese)

Malloy, K. D., Targett, T. E. (1991). Feeding, growth and survival of juvenile summer flounder Paralichthys dentatus: experimental analysis of the effects of temperature and salinity. Mar. Ecol. Prog. Ser 72: 213-223

Minami, T (1982). The early life history of flounder Paralichthys olivaceus. Bull. Jap. Soc. scient. Fish. 48: 1581-1588 (in Japanese, with English summary)

Nihira, A., Kawanobe, M., Hoshino, S. (1992). Size-dependent mortality of Japanese flounder, Paralichthys olivaceus, with fluorescent otolith-tags in Kashima-nada coastal waters. Bull. Ibaraki Pref. Fish. Exp. Stn 30: 65-70 (in Japanese, with English summary)

Nihira, A., Takase, H., Betsui, K., Ishikawa, K. (1988). Results of mark-recapture experiments of flounder Paralichthys olivaceus (Temminck et Schlegel) on the coastal region of Ibaraki Prefecture. Bull. Ibaraki Pref. Fish. Exp. Stn 26: 137-159 (in Japanese, with English summary)

Sato, Y. (1975). Studies on the life history of the bastard halibut, Paralichthys olivaceus (Temminck et Schlegel). near Sendai Bay. Bull. Tohoku reg. Fish. Res. Lab. 35: 15-30 (in Japanese, with English summary)

This article was submitted to the editor
Seikai, T., Kinoshita, I., Tanaka, M. (1993). Predation by crangonid shrimp on juvenile Japanese flounder under laboratory conditions. Nippon Suisan Gakk. 59: 321-326

Seikai, T., Tanangonan, J. B., Tanaka, M. (1986). Temperature influence on larval growth and metamorphosis of the Japanese flounder Paralichthys olivaceus in the laboratory. Bull. Jap. Soc. scient. Fish. 52: 977-982

Sudo, H., Goto, T., Ikemoto, R., Tomiyama, M., Azeta, M. (1992). Mortality of reared flounder (Paralichthys olivaceus) juveniles released in Shijiki Bay. Bull. Seikai Natl Fish. Res. Inst. 70: 29-37 (in Japanese, with English summary)

Tanaka, M., Goto, T., Tane, S., Ueno, M., Fujii, T., Sudo, H., Koshiishi, K., Hirota, Y. (1994). Regional differences in feeding and growth of juvenile Japanese flounder (Paralichthys olivaceus) among three nurseries. Neth. J. Sea Res. (in press)

Tanaka, M., Goto, T., Tomiyama, M., Sudo, H. (1989). Immigration, settlement and mortality of flounder (Paralichthys olivaceus) larvae and juveniles in a nursery ground, Shijiki Bay, Japan. Neth. J. Sea Res. 24: 57-67

Thayer, G. W., Schaaf, W. E., Angelovic, J. W., LaCroix, M. W. (1973). Caloric measurements of some esturine organisms Fish. Bull. U.S. 71: 289-296

Tsukamoto, K. (1985). Mass-marking of ayu eggs and larvae by tetracycline-tagging of otolith. Bull. Jap. Soc. Sci. Fish. 51: 903-911

Tsukamoto, K., Kuwada, H., Hirokawa, J., Oya, M., Sekiya, S. Fujimoto, H., Imaizumi, K. (1989). Size-dependent mortality of red sea bream, Pagrus major, juveniles released with fluorescent otolith-tags in News Bay, Japan. J. Fish Biol. 35: 59-69

van der Veer, H. W., Bergman, M. J. N. (1987). Predation by crustaceans on a newly settled 0-group plaice Pleuronectes platessa population in the western Wadden Sea Mar. Ecol. Prog. Ser. 35: 203-215

van der Veer, H. W., Pihl, L., Bergman, M. J. N. (1990). Recruitment mechanisms in North Sea plaice Pleuronectes platessa. Mar. Ecol. Prog. Ser. 64: 1-12

Yamashita, Y., Yamamoto, K., Nagahora, S., Igarashi, K., Yamada, H., Ishikawa, Y., Sakuma, O., Nakamoto, Y. (1993). Predation of fishes on the hatchery-raised Japanese flounder, Paralichthys olivaceus, fry in the coastal waters of Iwate Prefecture, northeastern Japan. Suisanzoshoku 41: 497-505 (in Japanese, with English summary)

Manuscript first received: September 10,1993

Revised version accepted: December 3, 1993 